\title{
Soil bacterial biodiversity is driven by long-term pasture management, poultry litter, and cattle manure inputs
}

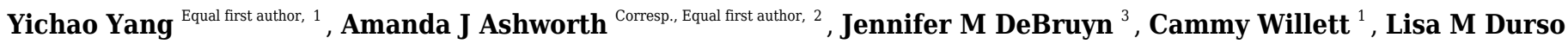 \\ ${ }^{4}$, Kim Cook ${ }^{5}$, Philip A Moore ${ }^{2}$, Phillip R Owens ${ }^{6}$ \\ ${ }^{1}$ Department of Crop, Soil, and Environmental Sciences, University of Arkansas at Fayetteville, Fayetteville, Arkansas, United States \\ 2 Poultry Production and Product Safety Research Unit, United States Department of Agriculture, Agricultural Research Service, Fayetteville, Arkansas, \\ United States \\ 3 Department of Biosystems Engineering \& Soil Science, University of Tennessee, Knoxville, Tennessee, United States \\ 4 Agroecosystem Management Research Unit, United States Department of Agriculture, Agricultural Research Service, Lincoln, Nebraska, United States \\ 5 Bacterial Epidemiology and Antimicrobial Resistance Research Unit, United States Department of Agriculture, Agricultural Research Service, Athens, \\ Georgia, United States \\ 6 Dale Bumpers Small Farms Research Center, United States of Agriculture, Agricultural Research Service, Booneville, Arkansas, United States
}

Corresponding Author: Amanda J Ashworth

Email address: Amanda.Ashworth@ars.usda.gov

Soil microorganisms are important for maintaining soil health, decomposing organic matter, and recycling nutrients in pasture systems. However, the impact of long-term conservation pasture management on soil microbial communities remains unclear. Therefore, soil microbiome responses to conservation pasture management is an important component of soil health, especially in the largest agricultural land-use in the U.S. The aim of this study was to identify soil microbiome community differences following 13-years of pasture management [hayed (no cattle), continuously grazed, rotationally grazed with a fenced, un-grazed and unfertilized buffer strip, and a control (no poultry litter or cattle manure inputs)]. Since 2004, all pastures (excluding the control) received annual poultry litter at a rate of $5.6 \mathrm{Mg}$ ha- 1 . Soil samples were collected at a $0-15 \mathrm{~cm}$ depth from 2016-2017 either pre or post poultry litter applications, and bacterial communities were characterized using Illumina 16S rRNA gene amplicon sequencing. Overall, pasture management influenced soil microbial community structure, and effects were different by year $(\mathrm{P}<0.05)$. Soils receiving no poultry litter or cattle manure had the lowest richness (Chao). Continuously grazed systems had greater $(\mathrm{P}<0.05)$ soil community richness, which corresponded with greater soil pH and nutrients. Consequently, continuously grazed systems may increase soil diversity, owing to continuous nutrient-rich manure deposition; however, this management strategy may adversely affect aboveground plant communities and water quality. These results suggest conservation pasture management (e.g. rotationally grazed systems) may not improve microbial diversity, albeit, buffer strips were reduced nutrients and bacterial movement as evident 
by low diversity and fertility in these areas compared to areas with manure or poultry litter inputs. Overall, animal inputs (litter or manure) increased soil microbiome diversity and may be a mechanism for improved soil health. 


\section{Soil Bacterial Biodiversity is Driven by Long-term Pasture Management, Poultry Litter, and Cattle Manure Inputs}

\section{Yichao Yang ${ }^{1}$, Amanda J. Ashworth ${ }^{2 *}$, Jennifer M. DeBruyn ${ }^{3}$, Cammy Willett $^{1}$, Lisa M. Durso ${ }^{4}$,} Kimberly Cook ${ }^{5}$, Philip A. Moore, Jr. ${ }^{2}$, and Phillip R. Owens ${ }^{6}$

${ }^{1}$ Department of Crop, Soil, and Environmental Sciences, University of Arkansas at Fayetteville, Fayetteville, Arkansas, United States;

${ }^{2}$ Poultry Production and Product Safety Research Unit, United States Department of Agriculture, Agricultural Research Service, Fayetteville, Arkansas, United States; *corresponding author, Amanda.Ashworth@ars.usda.gov

${ }^{3}$ Department of Biosystems Engineering \& Soil Science, University of Tennessee, Knoxville, Tennessee United States;

${ }^{4}$ Agroecosystem Management Research Unit, United States Department of Agriculture, Agricultural Research Service, Lincoln, Nebraska, United States;

${ }^{5}$ Bacterial Epidemiology and Antimicrobial Resistance Research Unit, United States Department of Agriculture, Agricultural Research Service, Athens, Georgia, United States;

${ }^{6}$ Dale Bumpers Small Farms Research Center, United States of Agriculture, Agricultural Research Service, Booneville, Arkansas, United States. 


\section{Abstract}

32 Soil microorganisms are important for maintaining soil health, decomposing organic matter, and 33 recycling nutrients in pasture systems. However, the impact of long-term conservation pasture management on soil microbial communities remains unclear. Therefore, soil microbiome responses to conservation pasture management is an important component of soil health, especially in the largest agricultural land-use in the U.S. The aim of this study was to identify soil microbiome community differences following 13-years of pasture management [hayed (no cattle), continuously grazed, rotationally grazed with a fenced, un-grazed and unfertilized buffer strip, and a control (no poultry litter or cattle manure inputs)]. Since 2004, all pastures (excluding the control) received annual poultry litter at a rate of $5.6 \mathrm{Mg} \mathrm{ha}^{-1}$. Soil samples were collected at a $0-15 \mathrm{~cm}$ depth from 2016-2017 either pre or post poultry litter applications, and bacterial communities were characterized using Illumina 16S rRNA gene amplicon sequencing. Overall, pasture management influenced soil microbial community structure, and effects were different by year $(P<0.05)$. Soils receiving no poultry litter or cattle manure had the lowest richness (Chao). Continuously grazed systems had greater $(P<0.05)$ soil community richness, which corresponded with greater soil $\mathrm{pH}$ and nutrients. Consequently, continuously grazed systems may increase soil diversity, owing to continuous nutrient-rich manure deposition; however, this management strategy may adversely affect aboveground plant communities and water quality. These results suggest conservation pasture management (e.g. rotationally grazed systems) may not improve microbial diversity, albeit, buffer strips were reduced nutrients and bacterial movement as evident by low diversity and fertility in these areas compared to areas with manure or poultry litter inputs. Overall, animal inputs (litter or manure) increased soil microbiome diversity and may be a mechanism for improved soil 53 health.

Keywords: soil microbiome; conservation pasture management; animal manure; microbial abundance.

Abbreviations: PERMANOVA, permutational analysis of variance; ANOVA, analysis of variance; PCoA, Principal Coordinates Analysis; operational taxonomic unit, OTU; LEfSe, Linear Discriminant Analysis Effect Size; CG, continuously grazed; H. hayed system; RBR, rotational grazing with a fenced riparian buffer. 
61

62

63

64

65

66

67

68

69

70

71

72

73

74

75

76

77

\section{Introduction}

Grasslands are the largest agricultural land-use category in the US, with 265 million hectares being used for grazing (Bigelow \& Borchers, 2012). A continuously grazed system (CG) is defined as animals grazing pastures for extended periods without allowing plants to recover (NRCS, 2016). In hayed (H) systems, forages are mechanically removed throughout the growing-season. Rotationally grazed (R) systems consist of strategically rotating livestock through paddocks to maximize forage productivity. This practice improves soil health (Pilon et al., 2017a), water quality, and conserves natural resources (USDA-NRCS, 2019). Another designated best management practice is the establishment of edge-of-field buffer or riparian buffer strips along water bodies. Riparian buffer strips decrease nutrient loading (Lovell \& Sullivan, 2006; Shearer \& Xiang, 2007).

Pasture management practices influence the soil nutrient status and consequently may affect soil bacterial communities. Overgrazing by livestock erodes soil (Webber et al., 2010; Van Oudenhoven et al., 2015). H systems improve soil quality by decreasing soil penetration resistance, bulk density, and improving aggregate stability and infiltration rates (Cox \& Amador, 2018). Rotationally grazed pastures with a fenced riparian buffer (RBR) reduces sediment loss compared to continuously grazed practices (Sanjari et al., 2009). Further, RBR reduces erosion (Pilon et al., 2017a).

Poultry litter is a common nutrient source for pastures. It includes macronutrients [nitrogen $(\mathrm{N})$, phosphorus $(\mathrm{P})$ and potassium $(\mathrm{K})]$, as well as trace elements (Stepheson, McCaskey \& Ruffin, 1990; Gerber, Opio \& Steinfeld, 2007). Poultry litter applied to pastures provides macronutrients and trace elements to soils, but repeated treatments may increase metals in soil (Han et al., 2000; Moore et al., 1998; Delaune \& Moore, 2014). Grazing also contributes to increased soil nutrients due to animal excreta (Vendramini et al., 2007). Nutrients from animal manure inputs (such as poultry litter and cattle manure) are also excellent microbial food sources (Ashworth et al., 2017). Trace elements are also required for bacterial growth and act as cofactors for essential enzymatic reactions in bacterial cells (He et al., 2014). Therefore, increased nutrients from poultry litter applications and grazing likely promotes bacterial richness and diversity, although their combined effects are unknown. 
While the physical and chemical impacts of pasture management on soil properties are well

91

92

93

94

95

96

97

98

99

100

101

102

103

104

105

106

107

108

109

110

111

112

113

114

115

116

117

118

119

understood, the long-term impact of common pasture strategies on the soil microbiome is less studied. The soil microbiome supports plant growth, carbon and nutrient cycling, and maintaining soil health (Jousset et al., 2011; USDA-NRCS, 2019; Fierer, 2017). However, whether grazing changes microbial function and diversity remains inconclusive. Ford et al. (2013) substantiated the claim that grazing affects the composition of soil microbial populations in grasslands via the variation in phospholipid fatty acid markers. Grazing may also reduce soil microbial biomass (Chen et al., 2016; Zhao et al., 2017) and soil microbial diversity (Olivera et al., 2016). However, others have reported that moderate grazing increases soil bacterial community diversity (Qu et al., 2016).

In addition to management, soil $\mathrm{pH}$, and soil moisture drives soil bacterial assemblages (Fierer, 2017; Fierer \& Jackson, 2006). Wu et al. (2017) suggested there is a strong relationship between bacterial diversity and soil $\mathrm{pH}$, with greater diversity occurring in basic soils and lower diversity being observed in acidic soils. Animal inputs (both poultry litter and cattle manure) may influence soil $\mathrm{pH}$ and soil $\mathrm{N}$, which can modify the makeup of soil microbial community and diversity by altering the nutrient status (Bardgett et al., 1997). Moreover, in a continentalscale assessment of soil bacterial communities, Fierer \& Jackson (2006) discovered that bacterial diversity is higher in neutral soils and lowest in acidic soils.

The present study used Illumina $16 \mathrm{~S}$ ribosomal RNA amplicon sequencing to identify the relative abundance and diversity of bacterial taxa in soils following 13-years of conservation pasture management. Species diversity is the measure of both richness and evenness, and considers not only the number of species present but also how the species are distributed. The goal of our study was to assess shifts in soil bacterial community structure and diversity based on long-term pasture management. We hypothesize that conservation pasture management practices (i.e., RBR) will have a more diverse soil bacterial community. Conversely, we suspect $\mathrm{H}$ systems will have a lower richness and diversity, owing to reduced cattle manure inputs, with soils receiving no poultry litter (control) having the lowest diversity. The aim of this study is to identify soil microbiome community differences following 13-years of pasture management systems and identify how soil biodiversity is impacted by cattle manure and poultry litter deposition to ultimately inform best management impacts of pasture systems. 
Materials and Methods

\section{Experimental design}

122 A field study was initiated in 2004 at the USDA-ARS Dale Bumpers Small Farms Research 123 Center in Booneville, Arkansas (N 3506'12”, W 9356'05’, $150 \mathrm{~m}$ altitude) to evaluate water

124 quality affects from conservation pasture management (Pilon et al., 2017a; 2017b; 2018). Fifteen

125 watersheds were constructed on a site with an average slope of $8 \%$ and on an Enders (fine,

126 mixed, active, thermic Typic Fragiudults) and Leadvale silt loam (fine-silty, siliceous,

127 semiactive, thermic Typic Fragiudults). Each watershed was 25 x $57 \mathrm{~m}$ for a total area of 0.14

128 ha. The dominant forage was common bermudagrass (Cynodon dactylon L.).

129 Three grazing management strategies (CG, H, and RBR) were implemented from 2004-2017 130 with three replications (Fig. 1). The H treatment was hayed three times annually (April, June, 131 and October) to a height of $10 \mathrm{~cm}$ with a rotary hay mower (no cattle in these watersheds area).

132 The CG watersheds were continuously grazed by one or two calves throughout the year (Pilon et 133 al., 2017a). The RBR watersheds were rotationally grazed based on forage height. Three calves

134 were placed in each RBR watershed when forage height was 20 to $25 \mathrm{~cm}$ and taken out when

135 forage heights were 10 to $15 \mathrm{~cm}$. The RBR watersheds had a $15.3-\mathrm{m}$ riparian buffer strip

136 containing four tree species [i.e., white oak (Quercus alba L.), green ash (Fraxinus

137 pennsylvanica Marshall), and pecan [Carya illinoinensis (Wangenh.) K. Koch] at the base of

138 each watershed (Fig. 1). These areas were un-grazed, did not receive poultry litter, and were 139 considered the control in this study (no poultry litter or cattle manure applied in this area). Each

140 watershed was divided, perpendicular to the slope into 3 zones (corresponding to shoulder, upper

141 backslope, and lower backslope positions), whereas the RBR consist of 4 zones (included the

142 control; Fig. 1). Poultry litter was land applied at a rate of $5.6 \mathrm{Mg} \mathrm{ha}^{-1}$ in April or May of each

143 year to each watershed (excluding the control). Since poultry litter was omitted in the buffered

144 area of the RBR treatment, application rates were identical on an aerial basis (RBR watersheds

145 received $658 \mathrm{~kg} \mathrm{plot}^{-1}$, whereas $\mathrm{H}$ and CG received $794 \mathrm{~kg} \mathrm{plot}^{-1}$ ). Poultry litter was obtained

146 annually from a commercial broiler farm near Booneville, AR.

147 Soil sampling procedures and analysis

148 Soil sampling was performed every April and July during 2016 and 2017, once pre-poultry 
149 litter application and the other post-litter application (four sampling dates total). Soil samples

150 were collected from $0-15 \mathrm{~cm}$ and homogenized with a minimum of 6 randomly selected points in

151 plot centers to preclude sampling borders, with three replicates total. To prevent contamination,

152 soil was taken using probes sterilized between plots with $70 \%$ ethanol $\left(\mathrm{C}_{2} \mathrm{H}_{6} \mathrm{O}\right)$. Samples from

153 each zone were collected and stored in a cooler for transport and stored at $-80^{\circ} \mathrm{C}$ for DNA

154 extraction. Soil $\mathrm{pH}$ was measured with a $\mathrm{pH}$ electrode and conductivity meter on a subsample of

155 the 1:10 soil extraction (SevenMulti, Mettler-Toledo). Total soluble nutrients (P, $\mathrm{K}, \mathrm{Ca}, \mathrm{Mg}$ )

156 were determined by inductively coupled argon plasma spectrometry (Varian Vista-PRO),

157 following a nitric-acid digestion using USEPA Method 3030E (USEPA, 1979).

158 DNA extraction, PCR amplification, and sequencing

159 DNA was extracted from each soil sample using the PowerSoil DNA extraction kit (MoBio

160 Laboratories) according to the manufacturer's directions. Briefly, the soil sample was fully

161 homogenized, and $0.25 \mathrm{~g}$ of soil was taken from each sample for DNA extraction. Extracted

162 DNA was quantified using Quant-It ${ }^{\mathrm{TM}}$ PicoGreen ${ }^{\circledR}$ (Invitrogen) dsDNA quantitation assay and

163 stored at $-20^{\circ} \mathrm{C}$.

164 Bacterial community composition was determined using Illumina Miseq sequencing of $16 \mathrm{~S}$

165 rRNA gene amplicons. Extracted DNA was sent to the University of Tennessee Genomic

166 Services Laboratory, where the V4 region of the 16S rRNA gene was amplified with barcoded

167 primers 515F and 806R (Caporaso et al., 2011). Amplicon libraries were pooled and 291 base-

168 paired end sequences were obtained on the Illumina MiSeq Platform, resulting in 15,172,724

169 total sequence reads. Reads were processed using the open source bioinformatics software

170 Mothur V 1.40.0 following the Miseq SOP protocol (Kozich et al., 2013). After the quality

171 control pipeline, 12,273,759 sequence reads remained using a 97\% similarity threshold to define

172 ribotypes in Mothur (19.11\% were deleted).

173 Data analysis and statistics

174 In this study, long-term pasture management (or the main effect; $\mathrm{H}, \mathrm{CG}, \mathrm{RBR}$, and the control)

175 was randomized, with zone or landscape position being the split-plot (based on slope position),

176 and sampling timing (pre or post-poultry litter application) being the split-split plot treatment

177 design. Prior to diversity analysis of soil microbial communities, the number of sequence reads 
178 in each sample were subsampled to 12,132 reads, the number of sequences present in the

179 smallest sample, to eliminate effects from uneven sampling depth. At this size, sequence

180 coverage for these libraries was good (0.97). The greengenes database was used to classify the

181 operational taxonomic unit (OTU) at the genus level using the Bayesian method (Cole et al.,

182 2009), thereafter relative abundance of all OTUs were summed within phylum and analyzed for

183 relative abundance of OTUs at the phylum level. Based on this subsampled dataset, richness was

184 calculated by using Chao index and diversity was calculated by measuring the inverse of

185 Simpson using Mothur, and differences by treatments were analyzed by ANOVA in the

186 statistical software R 3.5.1 (R Core Team, 2012) and JMP ${ }^{\circledR} 12$ (SAS Institute, 2007). Bacterial

187 community structure was quantified in a matrix of Bray-Curtis similarities, which was then

188 analyzed in a permutational analysis of variance (PERMANOVA) to compare bacterial

189 communities at the phylum level by fixed factors in PRIMER-E (Clarke \& Gorley, 2006).

190 Bacterial community structure was also quantified by using the ordination method of Principal

191 Coordinates Analysis (PCoA) on a matrix of Bray-Curtis dissimilarities using

192 MicrobiomeAnalyst (Dhariwal et al., 2017). Linear Discriminant Analysis Effect Size (LEfSe)

193 measurement was used to identify taxa differences between treatments with Galaxy (Segata et

194 al., 2011). Potential functional capacity of the soil bacterial communities were predicted using a

195 random forest algorithm based on the classification performance on different treatments using

196 MicrobiomeAnalyst (Dhariwal et al., 2017). MicrobiomeAnalyst was also applied to visualize

197 the KEGG metabolic networks along with pathway analysis. It was used to predict possible

198 effects of bacterial community composition shifts in function.

200 Results

201 Bacterial community composition based on sampling years, timing, and pasture management

202 There were differences in soil bacterial community structures at the phyla level between

203 sampling years (2016 and 2017) and treatments (CG, H, RBR, and the control; $P<0.05$ ).

204 Community structure did not alter based on timing of sampling (pre or post poultry litter

205 application; or April and July, respectively) ( $P>0.05$; Table 1 and Fig. 2). Although, there was a

206 poultry litter application timing x year effect on bacterial community structure for 2016 and 
207 2017. Based on PERMANOVA results, RBR and H communities differed at the phyla level

208 between pre and post poultry litter applications, however there were no differences between pre 209 and post applications for the CG and control treatments (Table 1; Fig. 2). OTU differences

$210(P<0.05)$ occurred at the genus level across systems, particularly following the long-term $\mathrm{CG}$

211 treatment and the control (Supplementary Fig. 1).

212 Ten phyla dominated soil bacterial communities: Proteobacteria (mean relative abundance of 213 all libraries was 30.8\%), Actinobacteria (28.9\%), Verrucomicrobia (8.8\%), Firmicutes (7.1\%),

214 Bacteriodetes (6.4\%), Planctomycetes (5.4\%), Chloroflexi (4.3\%), Gemmatimonadetes (2.9\%),

215 Saccharibacteria (1.5\%), and Armatimonadetes (0.3\%). Conservation pasture management

216 influenced the four most abundant phyla; however, these differences were not consistent between 217 years (Fig. 3). In both years, the relative abundance of Proteobacteria was higher in CG, H, and 218 RBR treatments compared to the control in 2016 ( $P=0.01)$ (Fig. 3A). In 2017, Proteobacteria had 219 greater $(P=0.026)$ relative abundance in $\mathrm{CG}$. The relative abundance of Actinobacteria did not 220 differ between treatments in $2016(P=0.33)$ (Fig. 3B), but rather decreased in the CG treatment 221 during 2017 (Fig. 3B). The relative abundance of Firmicutes did not differ $(P=0.26)$ between 222 treatments in 2016, but was elevated $(P=0.04)$ in RBR in 2017 (Fig. 3C). The relative abundance 223 of Verrucomicrobia (Fig. 3D) was greatest in the control for both years. The abundance of 224 Proteobacteria and Verrucomicrobia was different among pasture management treatments in both 225 sampling years $(P<0.05)$, while the relative abundance of Actinobacteria and Firmicutes was 226 only different between pasture management treatments and the control in 2017. Bacterial 227 community structure following 13-yrs of different pasture management treatments

PCoA of Bray-Curtis distance of the bacterial community structure visualized clustering differences between pasture management systems (Fig. 4). Due to the relative abundance of phylum differing based on pasture management, authors were then interested in identifying which taxa were most different between treatments. The LEfSe method was applied to identify which phylum were most discriminatory between the three pasture management systems and the control (Supplementary Fig. 2) (Segata et al., 2011). 
238 In both years, there were no effects of zone (or landscape position) on bacterial richness 239 (Table 2$)$. In addition, there were no effects $(P=0.75)$ of poultry litter application timing on 240 bacterial richness in 2016 (pre: $\mu=3330.66$ and post: $\mu=3352.37$ ), while there was an increase $241(P<0.0001)$ in richness during 2017 directly after litter applications (pre: $\mu=3029.73$ and post: $242 \mu=3378.63)$. Overall, pasture management effected bacterial richness in 2016, but not in 2017. 243 When considering bacterial diversity, there was no effects of pasture management, sampling 244 timing, or zone in either year. However, there were significant pasture management $\mathrm{x}$ timing 245 interaction for diversity during both years (Table 2). Samples collected prior to annual poultry 246 litter applications and under the H system had the lowest diversity $(\mu=120.37)$, whereas CG had 247 greater bacterial diversity ( $\mu=153.17$; Fig. 5). Across all samples collected post poultry litter applications, CG again had higher diversity $(\mu=155.45)$, with RBR having the lowest $(P<0.05)$ microbiome diversity $(\mu=130.28)$. Therefore, following 13-years of poultry litter applications and management system implementation, diversity increased following poultry litter applications (CG: $\mu=155.45$; H: $\mu=144.98$; RBR: $\mu=130.28$; control: $\mu=131.61$ ) compared to pre poultry litter applications (CG: $\mu=153.17$; H: $\mu=120.37$; RBR: $\mu=129.25$; control: $\mu=120.64$ ).

Bacterial community richness and diversity between pasture management treatments

254

255

256

257

258

259

260

261

262

263

264
Differences $(P=0.05 ; \mathrm{F}=2.75)$ occurred between treatments (Fig. 6), whereas no diversity differences occurred among pasture management treatments and the control (inverse Simpson's index $)(P=0.09 ; \mathrm{F}=2.15)$. Specifically, $C G$ had greater soil community richness $(\mu=3405.6)$ among all treatments followed by the control. In the present experiment, richness and diversity of soil bacterial assemblages in the control was lower $(\mu=3196.13$ and $\mu=14.19$, respectively) than other treatments $(\mathrm{H}: \mu=15.33$; $\mathrm{CG}: \mu=14.32$; RBR: $\mu=14.53)$.

\section{Functional prediction and accuracy}

We were interested in assessing potential shifts in nitrogen metabolism, as authors hypothesized that pasture systems receiving poultry litter and application timing would have different functional capacities with respect to $\mathrm{N}$ metabolism compared to the control. PICRUSt analysis identified $10 \mathrm{KEGG}$ hits related to $\mathrm{N}$ metabolism. However, there were no distinct 
265 changes in potential $\mathrm{N}$ metabolism based on poultry litter applications, as we were unable to 266 detect an influence of pasture management on $\mathrm{N}$ metabolism using this method. Considering the 267 limitation of PICRUSt, biased primers and database limitation may result in inaccurate 268 predictions (Ashworth et al., 2017). Additional functional diversity profiling analysis indicated 269 no significant differences among treatments based on these KEGG metabolic functions.

270

\section{Discussion}

272 Bacterial community composition based on sampling years, timing, and pasture management

273 Results illustrate the importance for evaluating soil ecology across time and space. Among 274 the identified dominant phyla, Actinobacteria are affected by soil moisture; considering, 275 Acidobacteria may decrease under greater precipitation and the presence of Proteobacteria 276 increases (Castro et al., 2010). Consequently, greater (70\%) humidity and soil moisture in 2017 277 corresponded with a lower relative abundance of Actinobacteria and a greater abundance of 278 Proteobacteria. Verrucomicrobia was the third most abundant phyla detected in this survey; 279 however, the ecology and soil functions of this phylum are not well understood. Although, 280 Verrucomicrobia is reportedly the most dominant bacterial phylum in grasslands (Bergmann et 281 al., 2011).

\section{Bacterial community structure following 13-yrs of different pasture management treatments}

283 PCoA results revealed that soils receiving neither poultry litter nor cattle manure harbored 284 distinct microbial communities compared to other treatments (Fig. 4). Overall, communities of

285 the three pasture management systems (H, RBR, and CG) were most similar, likely owing to 13 286 continuous years of poultry litter applications compared to the control (no poultry litter).

287 Previous research has also reported that long-term applications of poultry litter fundamentally 288 drives soil bacteria community structure, due to a combination of altered soil physicochemical 289 properties and poultry litter supplying it its own suite of microbes (Ashworth et al., 2017).

290 LEfSe results indicated that Verrucomicrobia and Abditibacterium (former phylum FBP) 291 (Tahon et al., 2018) were the two most different taxa between treatments. Verrucomicrobia was 292 very abundant in the control, while FBP was common in the CG treatment. Verrucomicrobia is 
293 ubiquitous in soil across a range of biomes in Antarctica, Europe, and the Americas and

294 Verrucomicrobia was the dominant bacterial phylum in grasslands and in subsurface soil

295 horizons (Bergmann et al., 2011). Navarrete et al. (2015) indicated that the relative proportion of

296 Verrucomicrobia decreased after soil fertility increased following deforestation. However, the

297 functions of both phyla in soil ecosystems are not well understood.

298

299

300

301

302

303

304

305

306

307

308

309

310

311

312

313

314

315

316

317

318

319

320

321

Effect of sample location and poultry litter application timing effects on alpha diversity of bacterial communities

There were no effects of zone (or landscape position) on bacterial richness (Table 2). This suggests microbiome communities did not vary greatly across landscape positions, but rather long-term management overrides any terrain attribute impacts. Results indicates that poultry litter application timing influenced bacterial diversity in $\mathrm{H}$ systems, with no affect occurring on CG. One possible explanation for this is that cattle continuously graze in the CG system, thus continuously depositing cattle manure inputs (both nutrients and microbes), making this treatment less affected by poultry litter application timing. In the pre-poultry litter sampling date, $\mathrm{H}$ had the lowest bacterial diversity; however, the bacterial diversity in $\mathrm{H}$ increased following poultry litter applications. This indicates that poultry litter applications, particularly in $\mathrm{H}$ systems, results in more phylogenetically diverse communities owing to more favorable food sources in the rhizosphere of these forage crops and greater substrate for microbial metabolism.

One possible explanation of CG having greater diversity is that that stressed plants excrete compounds in the rhizosphere that provides substrates and encourages bacterial growth. In addition, as noted above, this result may be a direct effect of poultry litter, or it may also be due to greater soil temperatures at time of sampling for the post poultry litter application treatment $(\mu$ temperature $=26.4^{\circ} \mathrm{C}$ in 2016 and $25.6^{\circ} \mathrm{C}$ in 2017) compared to the pre poultry litter application sampling period $\left(16.7^{\circ} \mathrm{C}\right.$ in 2016 and $14.4^{\circ} \mathrm{C}$ in 2017). This finding also corresponds with results from Ashworth et al. (2017), which observed lower richness and greater diversity when sampling under higher soil temperatures. Future research is needed to identify functional groups of soils amended with poultry litter in order to assess the potential for opportunistic pathogens (e.g., bacteroidetes) and identify potential functional shifts owing to manure deposition. Little research has been done on microbiome sequence differences between poultry litter and cattle manure

Peer] reviewing PDF | (2019:07:39358:2:0:NEW 30 Aug 2019) 
322 following soil deposition, although sampling area, strategy, and location consistencies are needed

323 for generating representative microbiomes for future microbiological-based manure studies.

324 Considering, Locatelli et al. (2017) found that when poultry litter was sampled in-house (prior to

325 land application), diversity (beta) and OUT abundance differed spatially. In a cattle feces

326 community compositional study, Wong et al. (2016) observed temporal shifts in composition

327 owing to moisture differences. Consequently, animal manure microbial ecology varies widely

328 based on environment, animal gut microbiome, sample type (fecal, litter), timing, and production 329 practices.

Bacterial community richness and diversity between pasture management treatments

331 Increases in grazing pressure increased soil communities, which was likely due to continuous

332 manure inputs in the CG treatment. This result is similar to that of Qu et al. (2016), which found

333 that increased grazing increases soil bacterial community diversity. Cattle manure additions

334 increase bacterial diversity, nutrient availability, aboveground plant biomass, and soil enzyme

335 activity (Das et al., 2017). Increased microbial richness may be one reason that animal manure

336 improves soil fertility and productivity in organic systems (Kravchenko, Snapp \& Roertson,

337 2017). In the present experiment, richness and diversity of soil bacterial assemblages in the

338 control was lower than other treatments, which suggests that cattle manure and poultry litter may

339 be responsible for increasing soil diversity. Ashworth et al. (2017) also demonstrated that poultry

340 litter applications increase diversity of soil bacterial communities. Conversely, some studies

341 suggest grazing intensity decreases the soil microbial diversity (Olivera et al., 2016).

342 Nonetheless, soil bacterial communities in agricultural soils are more temporally variable

343 because of management and inputs when compared with other unmanaged ecosystems, such as

344 grasslands and forest systems, which exhibit more seasonal stability (Ashworth et al., 2017;

345 DeBruyn et al., 2011; Lauber et al., 2013). Nonetheless, study results highlight the importance of

346 increased temporal and spatial sampling when evaluating soil microbes.

347 Many studies have established linkages between soil properties and soil microbiome (Lauber

348 et al., 2009; Rousk et al., 2010; Zhalnina et al., 2015; Fierer \& Jackson, 2006). The CG treatment

349 had greater soil $\mathrm{pH}, \mathrm{P}, \mathrm{K}, \mathrm{Ca}$, and $\mathrm{Mg}$ compared to the control and other two pasture

350 management systems (Table 3). In addition, nutrient concentrations in the control were lowest 
351 compared to $\mathrm{CG}, \mathrm{H}$ and RBR, which is in accordance with lower species richness in control

352 (Table 3). This suggests that soil systems management (such as grazing management and animal 353 manure inputs) may alter soil habitat by influencing the nutrient status and either stimulating or

354 hindering microbial activity (Balota et al., 2004). In addition, soil health practices (e.g.,

355 conservation tillage, cover crops, crop rotation, and nutrient management; USDA-NRCS, 2019)

356 may increase soil microbial biomass, resulting in a larger pool of soil microbial biomass $\mathrm{P}$

357 (Hallama et al., 2018). As such, greater microbial diversity may increase the microbial biomass $\mathrm{P}$

358 pool and exacerbate P losses in runoff (Turner and Haygarth, 2001; Blackwell et al., 2010).

359 Therefore, animal grazing density and nutrient management may drive soil biotic community

360 structure and soil health across agricultural landscapes and these results can be used to identify

361 best management practices for soil ecosystems.

362

363 Conclusion

364 Poultry litter and cattle manure inputs increased soil bacterial diversity and richness, as well

365 as altered the bacterial community composition in grasslands. In addition, these results suggest

366 that microbiome communities do not vary greatly across landscape positions; rather management

367 overrides impacts from terrain attributes. Richness differences found between long-term pasture

368 management systems indicates that the number of species in the CG system was greater than $\mathrm{H}$

369 and RBR, all of which were greater than soils receiving no poultry litter or manure inputs (the

370 control). Therefore, conservation agricultural practices (e.g. RBR) did not result in greater

371 diversity, therefore, continuously grazed systems, albeit not recommended when water quality is

372 a management consideration, did result in greater microbial diversity long-term. In addition, CG

373 systems resulted in greater soil $\mathrm{pH}, \mathrm{P}, \mathrm{K}, \mathrm{Ca}$, and $\mathrm{Mg}$, which corresponded with greater

374 phylogenetic diversity. This outcome is reasonable given that poultry litter has a high abundance

375 of bacteria, with $10^{9} \mathrm{CFU} / \mathrm{g}$ of aerobic bacteria (Lu et al., 2003). In addition, the high amount of

376 nutrients in poultry litter are cofactors for bacterial growth and multiplication. Therefore, not

377 surprisingly, the control (no poultry litter and cattle manure) had the lowest microbial diversity.

378 Overall, these results highlight that animal inputs (both poultry litter and cattle manure) influence

379 the soil $\mathrm{pH}$ and soil $\mathrm{N}$, which can modify the makeup of soil microbial community and diversity 
380 by altering the nutrient status. Future research will focus on the presence of antimicrobial 381 resistance genes in soils based on manure inputs.

382

\section{Acknowledgments}

384 We appreciate Dr. Mary Savin (The Department of Crop, Soil and Environmental Sciences, 385 University of Arkansas) for use of lab instruments. We also appreciate Taylor Cass Adams 386 (Poultry Science Department, University of Arkansas) for transporting samples and preparing the 387 experiments. Thanks for Jamie Hess (Poultry Science Department, University of Arkansas) for 388 helping with soil sample preparation. Mention of tradenames or commercial products in this 389 publication is solely for the purpose of providing specific information and does not imply 390 recommendation or endorsement by the U.S. Department of Agriculture.

391

392

393

394

395

396

397

398

399

400

401

402

403

404

405

406

407

408 
409

410

411 Figure 1. Schematic representation of the experimental set-up. Randomized complete block

412 design with 3 replications (9 watersheds total) from 2004-2018. All areas have received annual

413

414

415

416

417

418

419

420

421

422

423

424

425

426

427

428

429

430

431

432

433

434

435

436

437

438

\section{Figure Captions}

poultry litter applications (except for the control area). All watersheds received cattle manure excluding that of the Hayed treatment $(\mathrm{H})$.

Figure 2. Mean relative proportion of soil bacteria phyla by treatment x year. Pasture managements includes continuously grazed $(\mathrm{CG})$, hayed $(\mathrm{H})$, and rotational grazed with a fenced riparian buffer (RBR). The RBR treatment consists of an additional non-grazed zone without poultry litter or grazing (control). The order of colors is the same in the legend as the bars.

Figure 3. Relative abundance of bacteria phyla Proteobacteria (A), Actinobacteria (B), Firmicutes (C), and Verrucomicrobia (D) in years 2016 and 2017. Pasture managements includes continuously grazed $(\mathrm{CG})$, hayed $(\mathrm{H})$, and rotational grazed with a fenced riparian buffer (RBR). The RBR treatment consists of an additional non-grazed zone without poultry litter and grazing (control). Blue $=\mathrm{RBR}$, orange $=\mathrm{O}$, green $=\mathrm{H}$, and grey $=$ control.

Figure 4. Principal Coordinated Analysis (PCoA) of Bray-Curtis distances of bacterial community structures in different pasture managements. Pasture managements includes continuously grazed $(\mathrm{CG})$, hayed $(\mathrm{H})$, and rotational grazed with a fenced riparian buffer (RBR). The RBR treatment consists of an additional non-grazed zone without poultry litter and grazing (control). Pink $=$ control, green $=\mathrm{H}$, blue $=\mathrm{O}$, and purple $=\mathrm{RBR}$.

Figure 5. Diversity in soil bacterial communities affected by pasture management $\mathrm{x}$ timing via inverse Simpson's index estimates cross years (2016 and 2017). Pasture management treatments include continuously grazed $(\mathrm{CG})$, hayed $(\mathrm{H})$, and rotational grazed with a fenced riparian buffer (RBR). Pre and post indicate soil sampling before or after poultry litter was applied in these three treatments. The control is a non-grazed zone without poultry litter amendments at the downslope position of the RBR treatment. 
439 Figure 6. Mean richness (Chao Estimate) in soil bacterial communities. Pasture managements 440 include continuously grazed $(\mathrm{CG})$, hayed $(\mathrm{H})$, and rotational grazed with a fenced riparian buffer 441 (RBR). The RBR treatment consists of an additional non-grazed zone without poultry litter and 442 grazing (control).

443

444

445

446

447

448

449

450

451

452

453

454

455

456

457

458

459

460

461

462

463

464

465

466

467

468 


\section{Supplementary Figures}

470

471 Supplementary Figure 1. Stacked bar chart showing the mean relative abundance of top 20 OTUs

472 (genus level) following 13-years of pasture management including continuously grazed (CG),

473 hayed $(\mathrm{H})$, and rotational grazed with a fenced riparian buffer (RBR) in 2016 and 2017. The

474 RBR treatment consists of an additional non-grazed zone without poultry litter and grazing

475 (control). Classification of 'other' OTUs has been excluded from this Figure.

476

477 Supplementary Figure 2. Linear Discriminant Analysis Effect Size (LefSe) analysis showing

478 abundance of Verrucomicrobia and FBP phyla were significantly different between the control

479 and the continuously grazed (CG) pasture management treatments.

480

481

482

483

484

485

486

487

488

489

490

491

492

493

494

495

496

497

498 
499

500

501

502

503

504

505

506

507

508

509

510

511

512

513

514

515

516

517

518

519

520

521

522

523

524

525

526

527

528

\section{References}

Ashworth AJ, DeBruyn JM, Allen FL, Radosevich M, Owens PR. 2017. Microbial community structure is affected by cropping sequences and poultry litter under long-term no-tillage. Soil Biology and Biochemistry 114:210-219.

Balota E.L., Colozzi Filho, A., Andrade, D.S., Dick, R.P., 2004. Long-term tillage and crop rotation effects on microbial biomass and $\mathrm{C}$ and $\mathrm{N}$ mineralization in a Brazilian Oxisol. Soil and Tillage Research 77:137-145.

Bardgett RD, Leemans DK, Cook R, Hobbs PJ. 1997. Seasonality of the soil biota of grazed and ungrazed hill grasslands. Soil Biology and Biochemistry 29:1285-1294.

Bergmann GT, Bates ST, Eilers KG, Lauber CL, Caporaso JG, Walters WA, Knight R, Fierer N. 2011. The under-recognized dominance of Verrucomicrobia in soil bacterial communities. Soil Biology and Biochemistry 43:1450-1455.

Bigelow DP, and Borchers A. 2017. Major Uses of Land in the United States, 2012. EIB-178, U. S. Department of Agriculture, Economic Research Service, August 2017.

Blackwell MSA, Brookes PC, de le Fuente-Martinez N, Gordon H, Murray PJ, Snares KE, Williams JK, Bol R, Haygarth PM. 2010. Phosphorus solubilization and potential transfer to surface waters from the soil and microbial biomass following drying-rewetting and freezethawing. Advances in Agronomy 106:1-35.

Caporaso JG, Lauber CL, Walters WA, Berg-Lyons D, Lozupone CA, Turnbaugh PJ, Fierer N, Knight R. 2011. Global patterns of 16S rRNA diversity at a depth of millions of sequences per sample. Proceedings of the National Academy of Sciences of the United States of America. 108:4516-4522.

Castro HF, Classen AT, Austin EE, Norby RJ, Schadt CW. 2010. Soil microbial community responses to multiple experimental climate change drivers. Applied Environmental and Microbiology 76:999-1007.

Chen J, Zhou X, Wang J, Hruska T, Shi W, Cao J, Baocheng Zhang, Xu G, Yizhao C, Luo Y. 2016. Grazing exclusion reduced soil respiration but increased its temperature sensitivity in a Meadow Grassland on the Tibetan Plateau. Ecology and Evolution 6:675-687.

Clarke KR, Gorley, RN. 2006. PRIMER V6: User Manual/Tutorialedn. PRIMER-E Ltd., Plymouth. 
529 Cole JR, Wang Q, Cardenas E, Fish J, Chai B, Farris RJ, Kulam-Syed-Mohideen AS, McGarrell

530 DM, Marsh T, Garrity GM, Tiedje JM. 2009. The ribosomal database project: improved

$531 \quad$ alignments and new tools for rRNA analysis. Nucleic Acids Research 37: D141-145.

532 Cox AH, Amador JA. 2018. How grazing affects soil quality of soils formed in the glaciated

533 northeastern United States. Environmental Monitoring and Assessment 190:159.

534 Das S, Jeong ST, Das S, Kim PJ. 2017. Composted cattle manure increases microbial activity

535 and soil fertility more than composted swine manure in a submerged rice paddy. Frontiers in $536 \quad$ Microbiology 8:1702.

537 DeBruyn JM, Nixon LT, Fawaz MN, Johnson AM, Radosevich M. 2011. Global biogeography

538 and quantitative seasonal dynamics of Gemmatimonadetes in soil. Applied Environmental

539 and Microbiology 77:6295-6300.

540 DeLaune PB, Moore PA Jr. 2014. Factors affecting arsenic and copper runoff from fields

541 fertilized with poultry litter. Journal of Environmental Quality 43:1417-1423.

542 Dhariwal A, Chong J, Habib S, King IL, Agellon LB, Xia J. 2017. MicrobiomeAnalyst: a web-

543 based tool for comprehensive statistical, visual and meta-analysis of microbiome

544 data. Nucleic Acids Research 45:W180-W188.

545 Fierer N. 2017. Embracing the unknown: disentangling the complexities of the soil

546 microbiome. Nature Reviews Microbiology 15:579-590.

547 Fierer N, Jackson RB. 2006. The diversity and biogeography of soil bacterial

548 communities. Proceedings of the National Academy Sciences of the United States of America $549 \quad$ 103:626-631.

550 Fierer N, Bradford MA, Jackson RB. 2007. Toward an ecological classification of soil bacteria. $551 \quad$ Ecology 88:1354-1364.

552 Ford H, Rousk J, Garbutt A, Jones L, Jones DL. 2013. Grazing effects on microbial community

553 composition, growth and nutrient cycling in salt marsh and sand dune grasslands. Biology

$554 \quad$ and Fertility of Soils 49:89-98.

555 Gerber P, Opio C, Steinfeld H. 2007. Poultry production and the environment: A review. Animal

556 Production and Health Division, Food and Agriculture Organization of the United States

557 (FAO), Rome, Italy. http://www.fao.org/ag/againfo/

558 home/events/bangkok2007/docs/part2/2_2.pdf.). 
559 Han FX, Kingery WL, Selim HM, Gerard PD. 2000. Accumulation of heavy metals in a long560 term poultry waste amended soil. Soil Science 165:260-268.

561 Hallama M, Pekrun C, Lambers H, Kandeler E. 2018. Hidden miners: The roles of cover crops 562 and soil microorganisms in phosphorus cycling through agroecosystems. Plant Soil 434:7-45.

563 He Y, Chen Z, Liu X, Wang C, Lu W. 2014. Influence of trace elements mixture on bacterial 564

565

566

567 diversity and fermentation characteristics of liquid diet fermented with probiotics under air-

568 tight condition. PLOS ONE 9:e114218.

Jousset A, Schulz W, Scheu S, Eisenhauer N. 2011. Intraspecific genotypic richness and relatedness predict the invasibility of microbial communities. The ISME Journal 5:1108-

569 1114.

Kozich JJ, Westcott SL, Baxter NT, Highlander SK, Schloss PD. 2013. Development of a dual-

570

571

572 index sequencing strategy and curation pipeline for analyzing amplicon sequence data on the MiSeq Illumina sequencing platform. Applied Environmental and Microbiology 79:5112 5120.

Kravchenko AN, Snapp SS, Robertson GP. 2017. Field-scale experiments reveal persistent yield gaps in low-input and organic cropping systems. Proceedings of the National Academy Sciences of the United States of America 114:926-931.

Lauber CL, Hamady M, Knight R, Fierer N. 2009. Pyrosequencing-based assessment of soil pH as a predictor of soil bacterial community structure at the continental scale. Applied Environmental and Microbiology 75:5111-5120.

Lauber CL, Ramirez KS, Aanderud Z, Lennon J, Fierer N. 2013. Temporal variability in soil microbial communities across land-use types. The ISME Journal 7:1641-1650.

Locatelli A, KL Hiett, AC Caudill, MJ Rothrock. Do fecal and litter microbiomes vary within the major areas of a commercial poultry house, and does this affect sampling strategies for whole-house microbiomic studies? 2017. J. Appl. Poult. Res. 26: 325-336.

Lovell ST, and Sullivan WC. 2006. Environmental benefits of conservation buffers in the United States: Evidence, promise, and open questions. Agriculture, Ecosystems, \& Environment 112:249-260.

Lu J, Sanchez S, Hofacre C, Maurer JJ, Harmon BG, Lee MD. 2003. Evaluation of broiler litter with reference to the microbial composition as assessed by using $16 \mathrm{~S}$ rRNA and functional 

gene markers. Applied Environmental and Microbiology 69:901-908.

590

591

592

593

594

595

596

597

598

599

600

601

602

603

604

605

606

607

608

609

610

611

612

613

614

615

616

617

618

Moore PA Jr, Daniel TC, Gilmour JT, Shreve BR, Edwards DR, Wood BH. 1998. Decreasing metal runoff from poultry litter with aluminum sulfate. Journal of Environmental Quality 27:92-99.

Navarrete AA, Soares T, Rossetto R. Veen JAV, Tsai SM, Kuramae EE. 2015. Verrucomicrobial community structure and abundance as indicators for changes in chemical factors linked to soil fertility. Antonie van Leeuwenhoek 108:741.

Natural Resources Conservation Service (NRCS). 2016. Grazing management and soil health. https://www.nrcs.usda.gov/wps/PA_NRCSConsumption/download?cid=nrcseprd621806\&ex $t=p d f($ accessed 7. Dec. 2016).

Olivera NL, Prieto L, Bertiller MB, Ferrero MA. 2016. Sheep grazing and soil bacterial diversity in shrublands of the Patagonian Monte, Argentina. Journal of Arid Environments 125:16-20.

Pilon C, Moore PA, Pote DH, Pennington JH, Martin JW, Brauer DK, Raper RL, Dabney SM, Lee J. (2017a). Long-term effects of grazing management and buffer strips on soil erosion from pastures. Journal of Environmental Quality 46:364-372.

Pilon C, Moore PA, Pote DH, Martin JW, DeLaune PB. (2017b). Effects of grazing management and buffer strips on metal runoff from pastures fertilized with poultry litter. Journal of Environmental Quality 46:402-410.

Pilon C, Moore PA, Pote DH, Martin JW, Owens PR, Ashworth AJ, Miller DM, DeLaune PB. 2018. Grazing management and buffer strip impact on nitrogen runoff from pastures fertilized with poultry litter. Journal of Environmental Quality 48:297-304.

Qu TB, Du WC, Yuan X, Yang ZM, Liu DB, Wang DL, Yu LJ. 2016. Impacts of grazing intensity and plant community composition on soil bacterial community diversity in a steppe grassland. PLOS ONE 11:e0159680.

R Core Team, 2012. R: a Language and Environment for Statistical Computing. R Foundation for Statistical Computing, Vienna, Austria, ISBN 3-900051-07-0.

Rousk J, Bååth E, Brookes PC, Lauber CL, Lozupone C, Caporaso JG, Knight R, Fierer N. 2010. Soil bacterial and fungal communities across a $\mathrm{pH}$ gradient in an arable soil. The ISME Journal 4:1340-1351

Sanjari G, Yu B, Ghadiri H, Ciesiolka CAA, Rose CW. 2009. Effects of time-controlled grazing 
on runoff and sediment loss. Australian Journal of Soil Research 47:796-808.

620 SAS Institute, Inc, 2007. SAS/STAT 9.3 User's Guide (Cary, NC).

621 Segata N, Izard J, Waldron L, Gevers D, Miropolsky L, Garrett WS, Huttenhower C. 2011.

622 Metagenomic biomarker discovery and explanation. Genome Biology 12, R60.

623 Shearer KS, Xiang WN. The characteristics of riparian buffer studies. Journal of Environmental 624 Information 9:41-55.

625 Stephenson AH, McCaskey TA, Ruffin BG. 1990. A survey of broiler litter composition and 626 potential value as a nutrient resource. Biological Wastes 34:1-9.

627 Tahon G, Tytgat B, Lebbe L, Carlier A, Willems A. 2018. Abditibacterium utsteinense sp. nov., 628 the first cultivated member of candidate phylum FBP, isolated from ice-free Antarctic soil 629 samples. Systematic and Applied Microbioloy41:279-290

630 Turner BL, Haygarth, PM. 2001. Biogeochemistry: Phosphorus solubilization in rewetted soils. $631 \quad$ Nature 411:258.

632 U.S. Department of Agriculture. Soil Conservation Service. 1977. Soil survey of Logan County 633 Arkansas. USDA, Washington D.C.

634 USDA-NRCS. 2019. Soil health. USDA-NRCS. https://www.nrcs.usda.gov/

$635 \mathrm{wps} / \mathrm{portal} / \mathrm{nrcs} / \mathrm{main} /$ soils/health/ (accessed 5 Mar. 2019).

636 USEPA. 1979. Methods for chemical analysis of water and wastes. USEPA Rep. 600/4- 79-020.

637 USEPA, Washington, DC.

638 Van Oudenhoven APE, Veerkamp CJ, Alkemade R, Leemans R. 2015. Effects of different

639 management regimes on soil erosion and surface runoff in semi-arid to sub-humid

640 rangelands. Journal of Arid Environments 121:100-111.

641 Vendramini JMB, Silveira MLA, Dubeux JR, Sollenberger LE. 2007. Environmental impacts

642 and nutrient recycling on pastures grazed by cattle. Revista Brasileira de Zootecnia 36:139643149.

644 Webber DF, Mickelson SK, Ahmed SI, Russell JR, Powers WJ, Schultz RC, and Kovar JL.

645 2010. Livestock grazing and vegetative filter strip buffer effects on runoff sediment, nitrate, 646 and phosphorus losses. Journal of Soil and Water Conservation 65:34-41.

647 Wong K, TI Shaw, A Oladeinde, TC Glenn, B Oakley, M Molina. 2016. Rapid microbiome 648 changes in freshly deposited cow feces under field conditions. Frontiers in Microbiology 
$6497: 325-336$.

650 Wu Y, Zeng J, Zhu Q, Zhang Z. Lin X. 2017. pH is the primary determinant of the bacterial 651 community structure in agricultural soils impacted by polycyclic aromatic hydrocarbon 652 pollution. Scientific Reports 7:40093.

653 Zhalnina K, Dias R, de Quadros PD. Davis-Richardson A. Camargo FA. Clark IM, McGrath SP, 654 Hirsch PR, Triplett EW. 2015. Soil pH determines microbial diversity and composition in the 655 park grass experiment. Microbial Ecology 69:395-406.

656 Zhao F, Ren C, Shelton S, Wang Z, Pang G, Chen J, Wang J. 2017. Grazing intensity influence 657 soil microbial communities and their implications for soil respiration. Agriculture,

$658 \quad$ Ecosystems and Environment 249:50-56.

659

660

661

662

663

664

665

666

667

668

669

670

671

672

673

674

675

676

677

678 


\section{Table $\mathbf{1}$ (on next page)}

PERMANOVA in bacterial community structure by years, timing (pre and post poultry litterapplication season), and pasture management.

PERMANOVA results illustrate differences in bacterial community structure by single factor of sample collection years (2016 and 2017), timing (pre and post poultry litter application season), and pasture management, as well as two factors (Year $\times$ Timing, Year $\times$ Pasture management, and timing $\times$ pasture management) and three factors (Year $x$ Timing $x$ Pasture management) in Booneville, AR from 2016-2017. 
1 Table 1. PERMANOVA results illustrate differences in bacterial community structure by single

2 factor of sample collection years (2016 and 2017), timing (pre and post poultry litter application

3 season), and pasture management, as well as two factors (Year x Timing, Year x Pasture

4 management, and timing $\mathrm{x}$ pasture management) and three factors (Year $\mathrm{x}$ Timing $\mathrm{x}$ Pasture

5 management) in Booneville, AR from 2016-2017.

6

\begin{tabular}{lll}
\hline Factor & Pseudo-F & P-value \\
\hline Year & 7.70 & $0.001^{*}$ \\
Timing (Pre-Post) & 1.61 & 0.161 \\
Pasture Management & 8.87 & $0.001^{*}$ \\
Year x Timing & 2.88 & $0.028^{*}$ \\
Year x Pasture Management & 2.51 & $0.008^{*}$ \\
Timing x Pasture Management & 1.15 & 0.317 \\
Year x Timing x Pasture & 1.15 & 0.306 \\
\hline & Year separation & \\
\hline Factor & 2016 & 2017 \\
\hline Timing (Pre-Post) & $3.31(P=0.006)^{*}$ & $1.67(\mathrm{P}=0.15)$ \\
Pasture Management & $4.38(P=0.004)^{*}$ & $6.07(P=0.001)^{*}$ \\
Timing x Pasture & $1.11(P=0.307)$ & $1.06(P=0.389)$ \\
\hline
\end{tabular}

$7 \quad * P<0.05$ 


\section{Table 2 (on next page)}

ANOVA of richness and diversity in bacterial community structure following 13-years ofpasture management, sampling date and zone.

ANOVA results illustrating richness and diversity in bacterial community structure by single factor of pasture management, sampling date and zone, as well as two factors (pasture management and timing) at Booneville, AR from 2016-2017. 
1 Table 2. ANOVA results illustrating richness and diversity in bacterial community structure by 2 single factor of pasture management, sampling date and zone, as well as two factors (pasture 3 management and timing) at Booneville, AR from 2016-2017.

4

5

6

7

8

9

10

11

12

13

14

15

16

17

18

19

20

21

\begin{tabular}{lllll}
\hline Parameter & Factor & df & F-value & P-value \\
\hline Richness & 2016 & & & \\
\cline { 2 - 5 } & Pasture Management & 3 & 3.03 & $0.0367^{*}$ \\
& Timing (Pre-Post) & 1 & 0.09 & 0.7583 \\
& Zone & 2 & 1.87 & 0.1642 \\
& Pasture x Timing & 3 & 0.45 & 0.7147 \\
\cline { 2 - 5 } & 2017 & & \\
\cline { 2 - 5 } & Pasture Management & 3 & 1.30 & 0.2832 \\
& Timing (Pre-Post) & 1 & 17.55 & $<0.0001^{*}$ \\
& Zone & 2 & 0.21 & 0.8095 \\
& Pasture x Timing & 3 & 0.49 & 0.6876 \\
\hline Diversity & 2016 & & \\
& Pasture Management & 3 & 0.85 & 0.4679 \\
& Timing (Pre-Post) & 1 & 1.34 & 0.2501 \\
& Zone & 2 & 1.58 & 0.2146 \\
& Pasture x Timing & 3 & 4.16 & $0.0093^{*}$ \\
\cline { 2 - 5 } & 2017 & & \\
\cline { 2 - 5 } & Pasture Management & 3 & 0.79 & 0.5026 \\
& Timing (Pre-Post) & 1 & 1.04 & 0.3108 \\
& Zone & 2 & 1.80 & 0.1740 \\
& Pasture x Timing & 3 & 3.12 & $0.0318^{*}$ \\
\hline
\end{tabular}




\section{Table 3 (on next page)}

Soil chemical and physical results based on pasture management.

Soil sample analysis $(0-15 \mathrm{~cm})$ based on pasture management at Booneville, AR in 2016 and 2017. Pasture management includes continuously grazed (CG), hayed $(H)$ and rotationally grazed treatment with a fenced riparian buffer (RBR). Poultry litter was applied in these three treatments. The RBR treatment consisted of an additional non-grazed zone without poultry litter amendments, which served as the control. 
1 Table 3. Soil sample analysis $(0-15 \mathrm{~cm})$ based on pasture management at Booneville, AR in 2016 2 and 2017. Pasture management includes continuously grazed (CG), hayed (H) and rotationally 3 grazed treatment with a fenced riparian buffer (RBR). Poultry litter was applied in these three 4 treatments. The RBR treatment consisted of an additional non-grazed zone without poultry litter 5 amendments, which served as the control.

6

7

8

9

10

11

12

13

14

15

16

\begin{tabular}{lllllll}
\hline 2016 & Treatment & $\mathrm{pH}$ & $\mathrm{P}$ & $\mathrm{K}$ & $\mathrm{Ca}$ & $\mathrm{Mg}$ \\
\cline { 3 - 7 } & & & & $\mathrm{Mg} \mathrm{kg}^{-1}$ & & \\
\hline & CG & 5.90 & 39.33 & 104.53 & 41.82 & 13.99 \\
& $\mathrm{H}$ & 5.65 & 30.44 & 49.02 & 39.09 & 11.73 \\
& RBR & 5.67 & 38.26 & 77.00 & 37.34 & 10.42 \\
& Control & 5.71 & 5.01 & 39.13 & 25.90 & 5.93 \\
\hline 2017 & CG & 5.48 & 54.72 & 212.74 & 55.28 & 21.77 \\
& H & 4.95 & 39.56 & 52.13 & 45.52 & 13.74 \\
& RBR & 4.99 & 44.04 & 109.88 & 45.16 & 12.91 \\
& Control & 5.20 & 5.31 & 47.20 & 31.07 & 6.93 \\
\hline
\end{tabular}




\section{Figure 1}

Schematicrepresentation of the experimental set-up.

Schematic representation of the experimental set-up. Randomized complete block design

with 3 replications (9 watersheds total) from 2004-2018. All areas have received annual

poultry litter applications (except for the control area). All watersheds received cattle manure

excluding that of the Hayed treatment $(\mathrm{H})$.

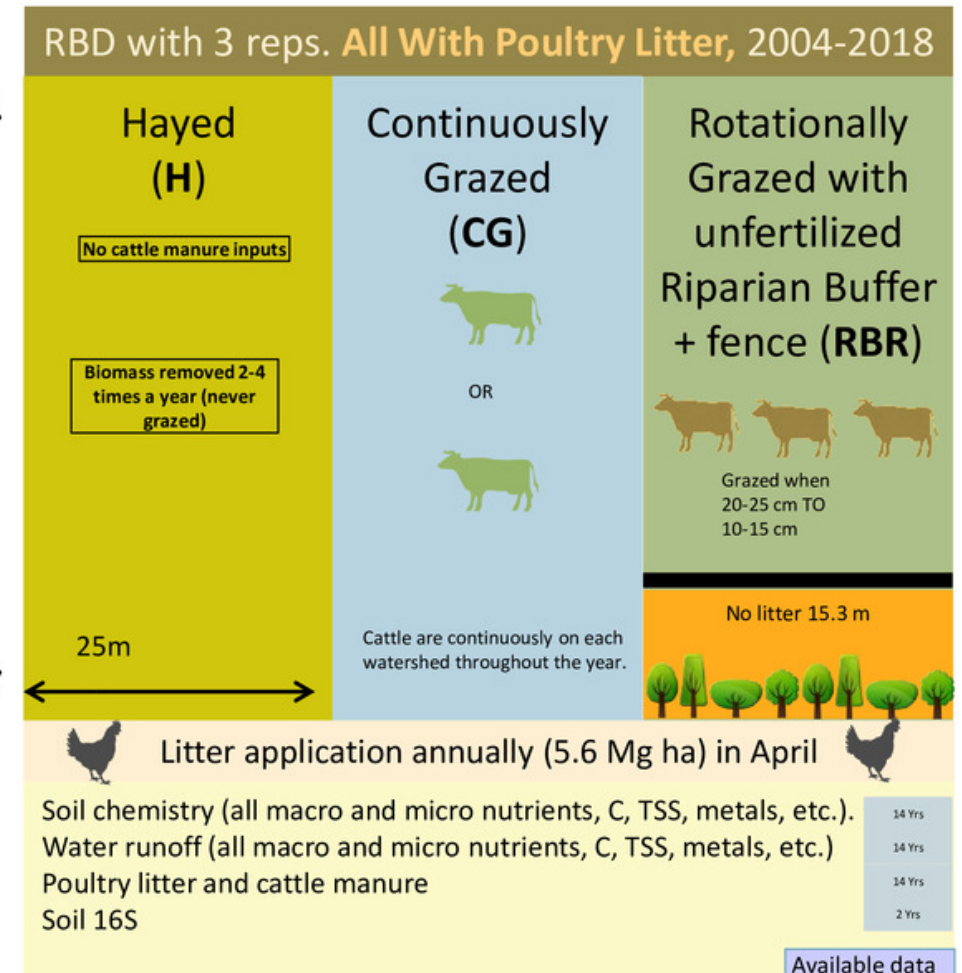


Figure 2

Mean relative proportion of soil bacteria phyla by treatment $x$ year.

Mean relative proportion of soil bacteria phyla by treatment $\mathrm{x}$ year. Pasture managements includes continuously grazed (CG), hayed $(\mathrm{H})$, and rotational grazed with a fenced riparian buffer (RBR). The RBR treatment consists of an additional non-grazed zone without poultry litter or grazing (control). The order of colors is the same in the legend as the bars. 


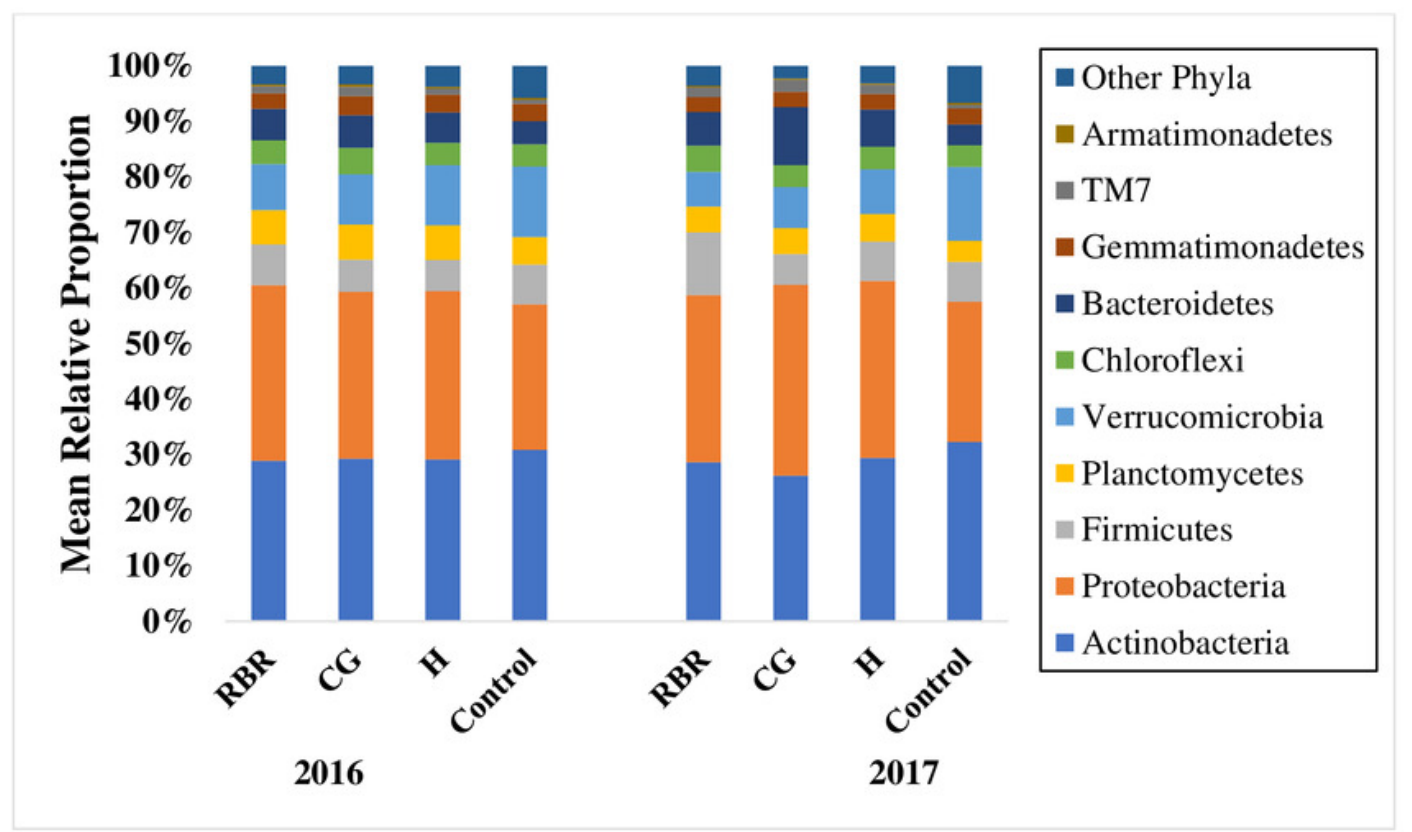


Figure 3

Relative abundance of bacteria phyla.

Relative abundance of bacteria phyla Proteobacteria (A), Actinobacteria (B), Firmicutes (C), and Verrucomicrobia (D) in years 2016 and 2017. Pasture managements includes continuously grazed (CG), hayed $(H)$, and rotational grazed with a fenced riparian buffer (RBR). The RBR treatment consists of an additional non-grazed zone without poultry litter and grazing (control). Blue=RBR, orange $=0, g r e e n=H$, and grey=control.

\section{Proteobacteria}

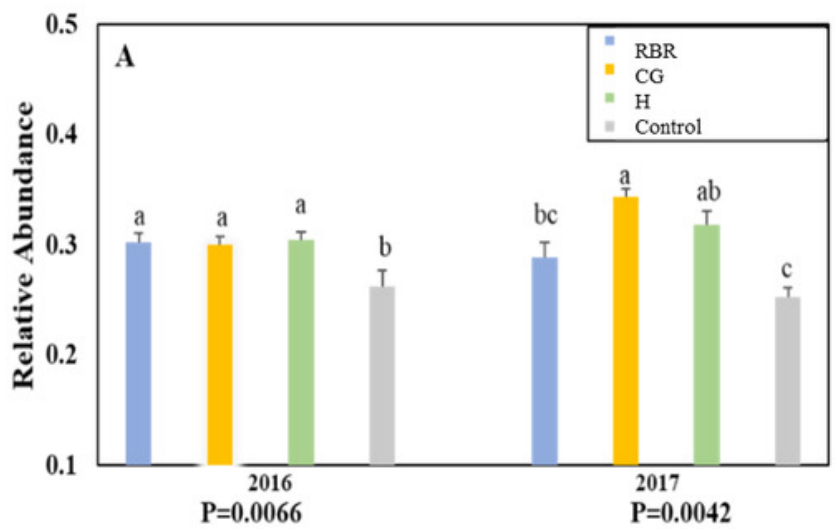

Firmicutes

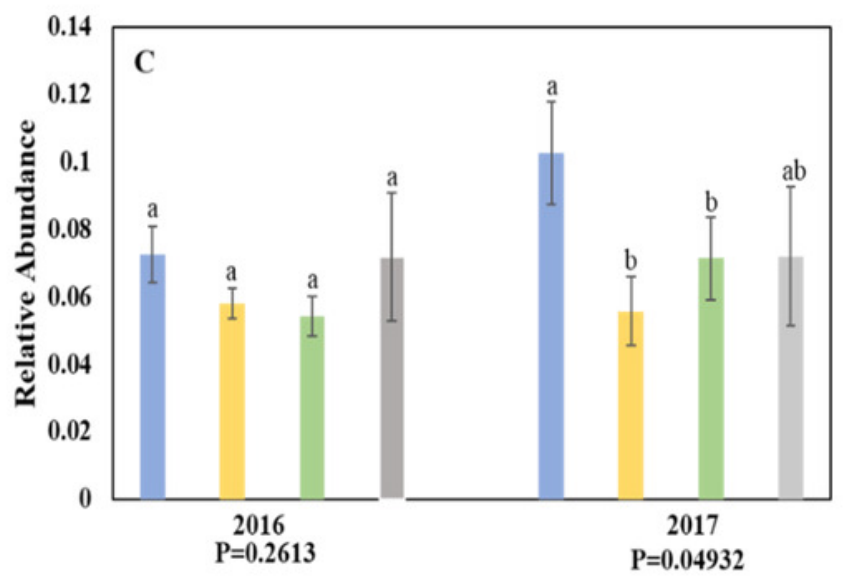

Actinobacteria

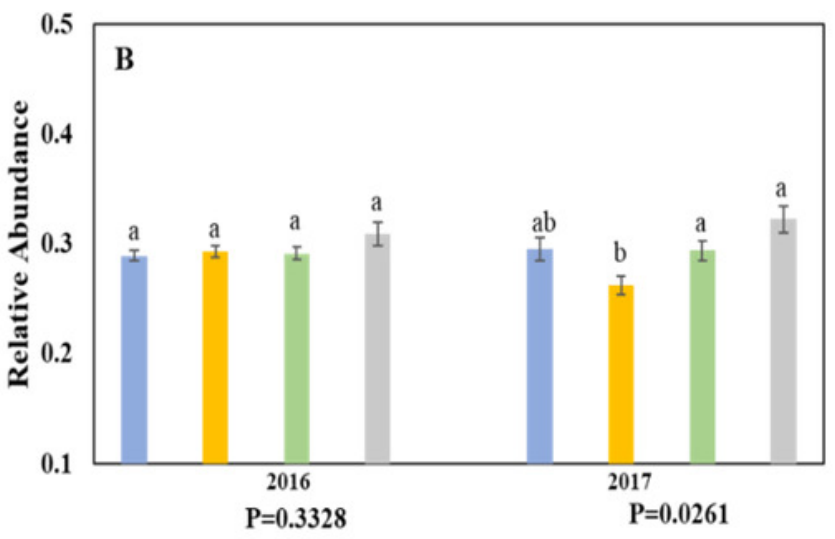

Verrucomicrobia

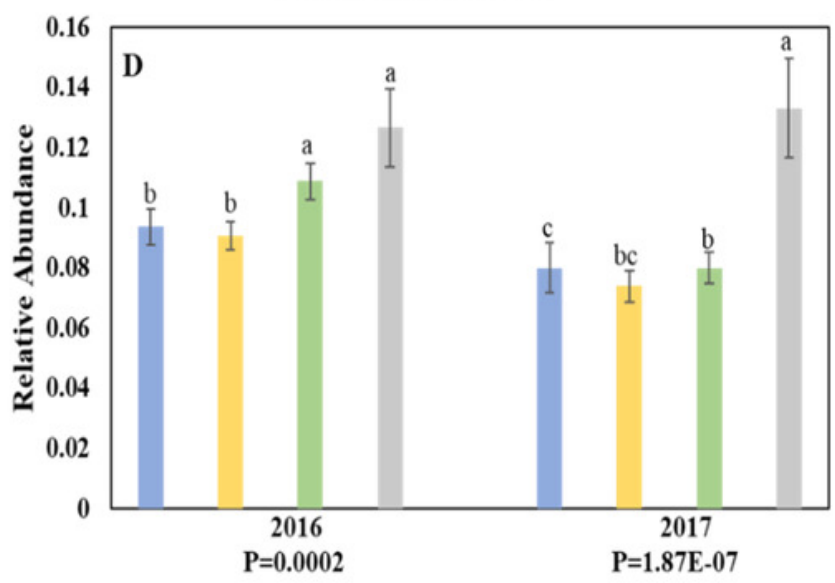




\section{Figure 4}

PCA of bacterial community structure.

Principal Coordinated Analysis (PCoA) of Bray-Curtis distances of bacterial community structures in different pasture managements. Pasture managements includes continuously grazed (CG), hayed (H), and rotational grazed with a fenced riparian buffer (RBR). The RBR treatment consists of an additional non-grazed zone without poultry litter and grazing (control). Pink $=$ control, green $=H$, blue $=0$, and purple $=$ RBR.

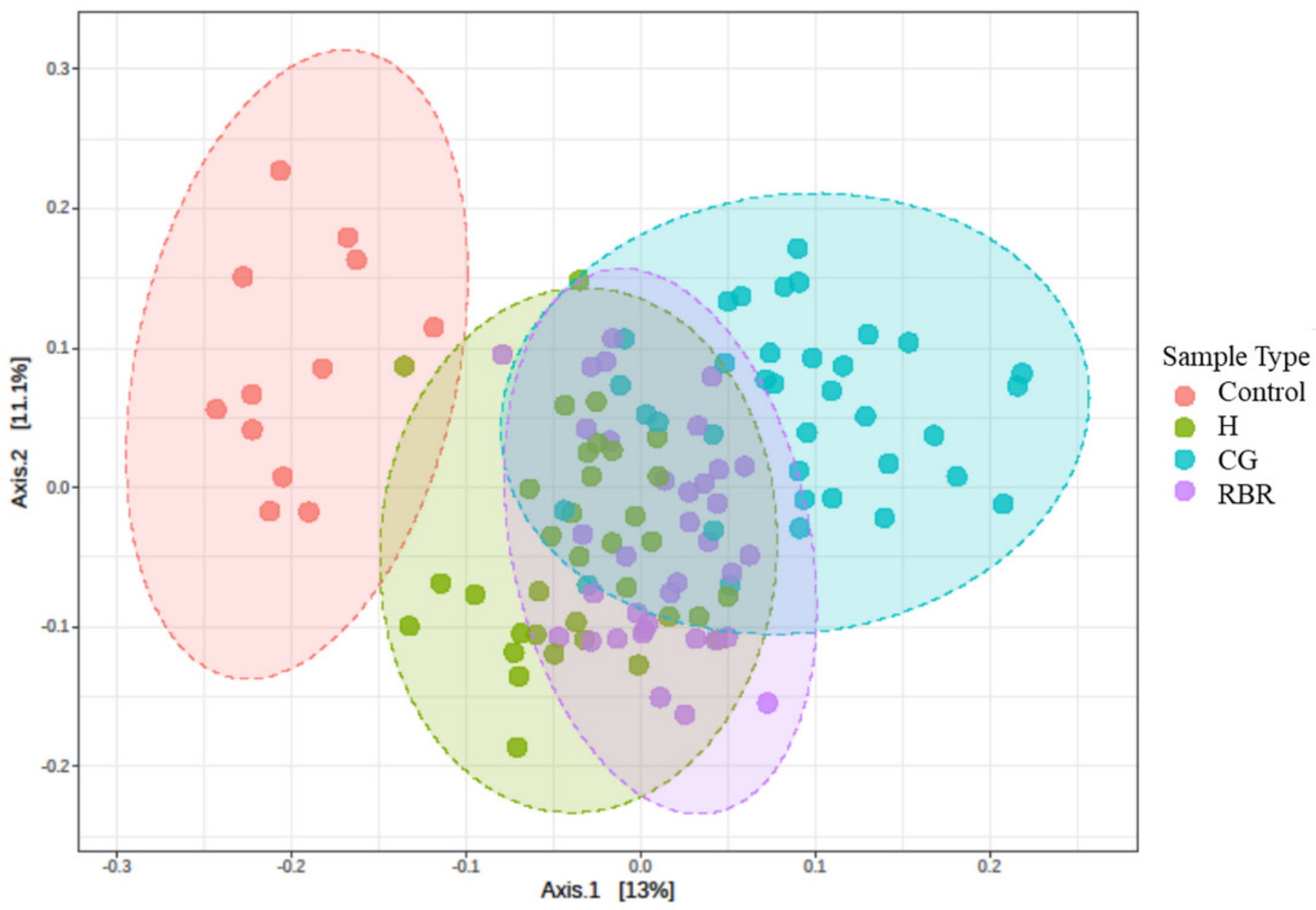




\section{Figure 5}

Diversity in soil bacterial communities affected by pasture management $\mathrm{x}$ timing via inverse Simpson's index estimates cross years (2016 and 2017).

Diversity in soil bacterial communities affected by pasture management $x$ timing via inverse Simpson's index estimates cross years (2016 and 2017). Pasture management treatments include continuously grazed $(\mathrm{CG})$, hayed $(\mathrm{H})$, and rotational grazed with a fenced riparian buffer (RBR). Pre and post indicate soil sampling before or after poultry litter was applied in these three treatments. The control is a non-grazed zone without poultry litter amendments at the downslope position of the RBR treatment.

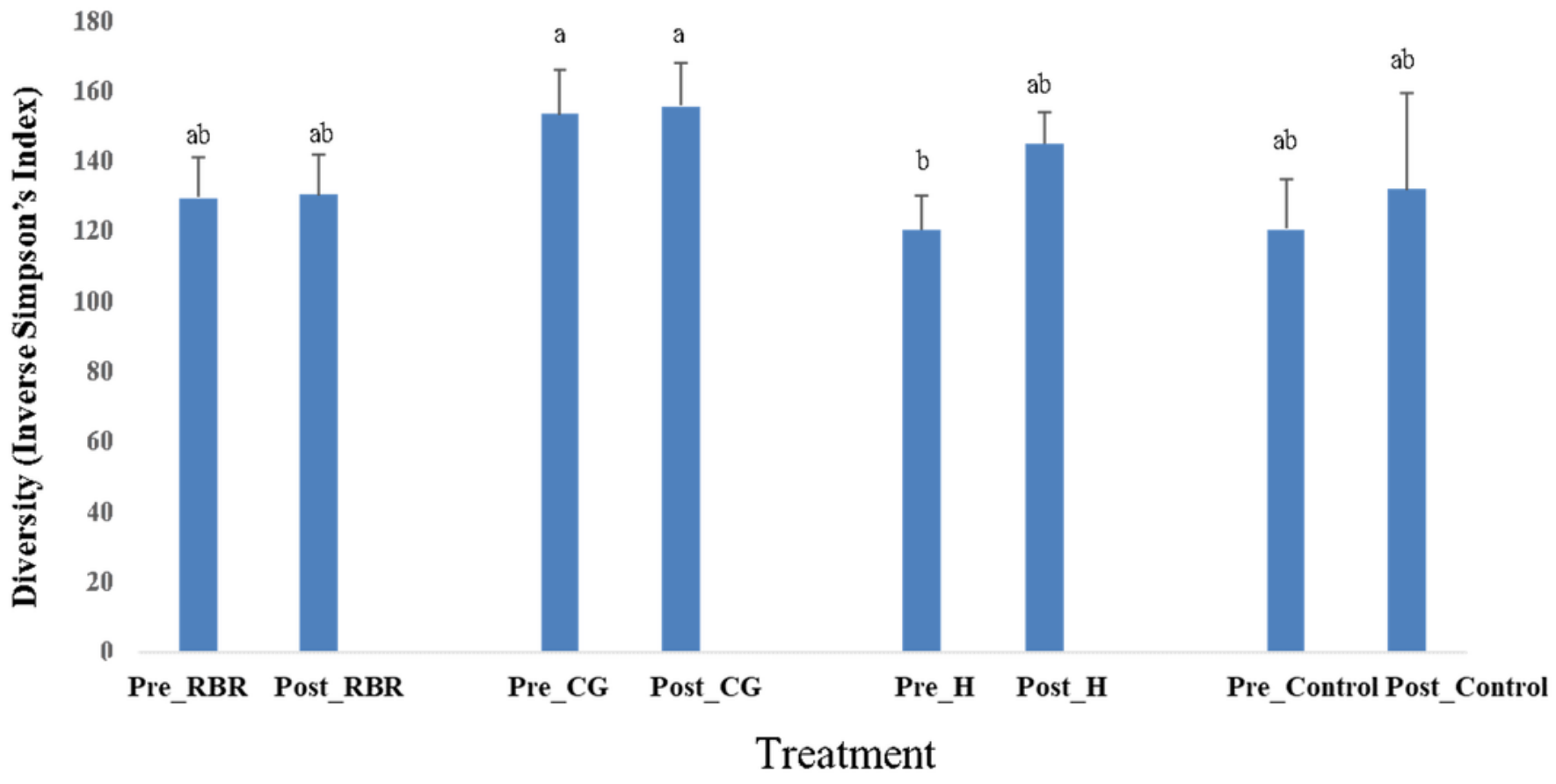


Figure 6

Mean richness (Chao Estimate) in soil bacterial communities.

Mean richness (Chao Estimate) in soil bacterial communities . Pasture managements include continuously grazed $(\mathrm{CG})$, hayed $(\mathrm{H})$, and rotational grazed with a fenced riparian buffer (RBR). The RBR treatment consists of an additional non-grazed zone without poultry litter and grazing (control).

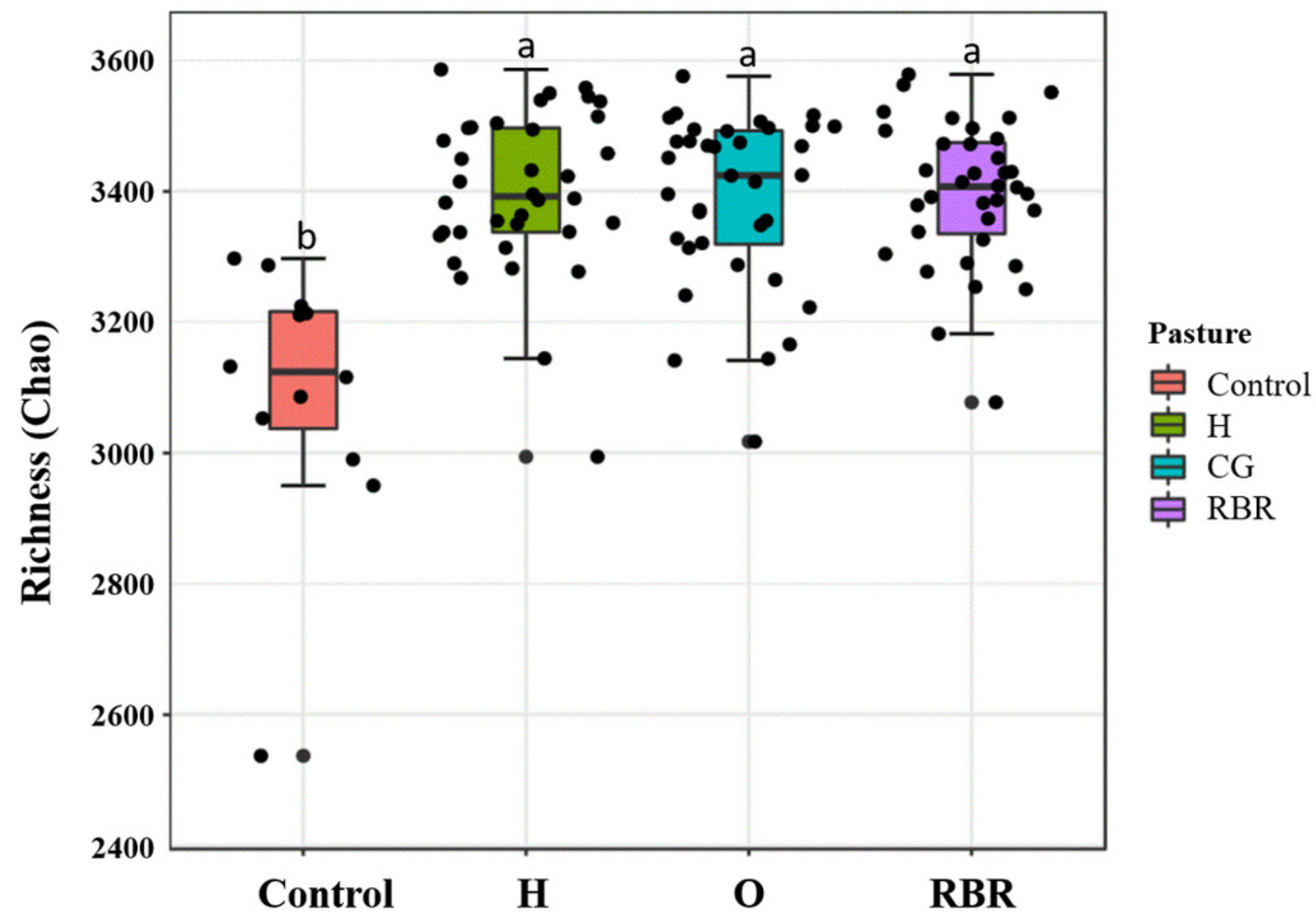

